NASA/TM-2000-210242

AIAA-2000-2908

Simulation of a Flywheel Electrical System for Aerospace Applications

Long V. Truong, Frederick J. Wolff, and Narayan V. Dravid Glenn Research Center, Cleveland, Ohio 
Since its founding, NASA has been dedicated to the advancement of aeronautics and space science. The NASA Scientific and Technical Information (STI) Program Office plays a key part in helping NASA maintain this important role.

The NASA STI Program Office is operated by Langley Research Center, the Lead Center for NASA's scientific and technical information. The NASA STI Program Office provides access to the NASA STI Database, the largest collection of aeronautical and space science STI in the world. The Program Office is also NASA's institutional mechanism for disseminating the results of its research and development activities. These results are published by NASA in the NASA STI Report Series, which includes the following report types:

- TECHNICAL PUBLICATION. Reports of completed research or a major significant phase of research that present the results of NASA programs and include extensive data or theoretical analysis. Includes compilations of significant scientific and technical data and information deemed to be of continuing reference value. NASA's counterpart of peerreviewed formal professional papers but has less stringent limitations on manuscript length and extent of graphic presentations.

- TECHNICAL MEMORANDUM. Scientific and technical findings that are preliminary or of specialized interest, e.g., quick release reports, working papers, and bibliographies that contain minimal annotation. Does not contain extensive analysis.

- CONTRACTOR REPORT. Scientific and technical findings by NASA-sponsored contractors and grantees.
- CONFERENCE PUBLICATION. Collected papers from scientific and technical conferences, symposia, seminars, or other meetings sponsored or cosponsored by NASA.

- SPECIAL PUBLICATION. Scientific, technical, or historical information from NASA programs, projects, and missions, often concerned with subjects having substantial public interest.

- TECHNICAL TRANSLATION. Englishlanguage translations of foreign scientific and technical material pertinent to NASA's mission.

Specialized services that complement the STI Program Office's diverse offerings include creating custom thesauri, building customized data bases, organizing and publishing research results ... even providing videos.

For more information about the NASA STI Program Office, see the following:

- Access the NASA STI Program Home Page at $h t t p: / / w w w . s t i . n a s a . g o v$

- E-mail your question via the Internet to help@sti.nasa.gov

- Fax your question to the NASA Access Help Desk at (301) 621-0134

- Telephone the NASA Access Help Desk at (301) 621-0390

- Write to: NASA Access Help Desk NASA Center for AeroSpace Information 7121 Standard Drive Hanover, MD 21076 
NASA/TM-2000-210242

\section{Simulation of a Flywheel Electrical System for Aerospace Applications}

Long V. Truong, Frederick J. Wolff, and Narayan V. Dravid Glenn Research Center, Cleveland, Ohio

Prepared for the

35th Intersociety Energy Conversion Engineering Conference sponsored by the American Institute of Aeronautics and Astronautics Las Vegas, Nevada, July 24-28, 2000

National Aeronautics and Space Administration

Glenn Research Center 


\section{Acknowledgments}

The authors thank Ray Beach from NASA Glenn and John Biess from U.S. Flywheel Systems of Newbury, California, for their advice and support.

Trade names or manufacturers' names are used in this report for identification only. This usage does not constitute an official endorsement, either expressed or implied, by the National Aeronautics and Space Administration.

This report is a preprint of a paper intended for presentation at a conference. Because of changes that may be made before formal publication, this preprint is made available with the understanding that it will not be cited or reproduced without the permission of the author.

Available from

NASA Center for Aerospace Information

7121 Standard Drive

Hanover, MD 21076

Price Code: A03
National Technical Information Service 5285 Port Royal Road Springfield, VA 22100

Price Code: A03 
AIAA-2000-2908

\title{
SIMULATION OF A FLYWHEEL ELECTRICAL SYSTEM FOR AEROSPACE APPLICATIONS
}

\author{
Long V. Truong," Frederick J. Wolff," and Narayan V. Dravid" \\ National Aeronautics and Space Administration \\ Glenn Research Center \\ Cleveland, Ohio
}

\begin{abstract}
A Flywheel Energy Storage Demonstration Project was initiated at the NASA Glenn Research Center as a possible replacement for the battery energy storage system on the International Space Station (ISS). While the hardware fabrication work was being performed at a university and contractor's facility, the related simulation activity was begun at Glenn. At the top level, Glenn researchers simulated the operation of the ISS primary electrical system (as described in another paper) with the Flywheel Energy Storage Unit (FESU) replacing one Battery Charge and Discharge Unit (BCDU). The FESU consists of a Permanent Magnet Synchronous Motor/Generator (PMSM), which is connected to the flywheel; the power electronics that connects the PMSM to the ISS direct-current bus; and the associated controller. The PMSM model is still under development, but this paper describes the rest of the FESU model-the simulation of the converter and the associated control system that regulates energy transfer to and from the flywheel.
\end{abstract}

\section{INTRODUCTION}

Spacecraft electrical power systems, in general, convert solar energy into usable electrical energy. For low Earth orbit, a rechargeable energy storage system is necessary to supply loads during the eclipse period as well as to provide backup power. Traditionally, space-qualified electrochemical storage batteries have served this purpose. However, unless there is a provision to replace such batteries often, they can limit the life of the spacecraft power system.

To address this need, researchers at the NASA Glenn Research Center at Lewis Field are developing an electromechanical energy storage (flywheel) system as

*Electrical engineer.

Copyright 12000 by the American Institute of Aeronautics and Astronautics, Inc. No copyright is asserted in the United States under Title 17, U.S. Code. The U.S. Government has a royalty-free license to exercise all rights under the copyright claimed herein for Government purposes. All other rights are reserved by the copyright owner. a battery replacement. In terrestrial systems, flywheels are often used as load equalizers. In space systems, flywheels have been used extensively for attitude control.

The new development intends to use the flywheel for both energy storage and attitude control. It is a joint industry-NASA effort. Naturally, the energy storage requirements for battery replacement are much higher than those for attitude control.

A comparison between flywheel and $\mathrm{NiH}_{2}$ battery systems for the EOS-AM1 type spacecraft' showed that a flywheel system would be much smaller and lighter: a 35 percent lighter mass, a 55 percent smaller volume, and a 6.7 percent smaller area needed for the solar array. For more information on NASA's flywheel programs, current status, business opportunities, and related issues, please refer to Glenn's space power web site. ${ }^{2}$

At the top level, Glenn researchers are modeling the ISS primary electrical system ${ }^{3}$ with a new Flywheel Energy Storage Unit (FESU) replacing one Battery Charge and Discharge Unit (BCDU). At the next level, the FESU will be modeled to account for the dynamics between the direct current $(\mathrm{dc})$ to three-phase alternating current (ac) converter and the motor model. In addition, a separate motor modeling activity is taking place, both in the circuit domain and in the finite element modeling (electromagnetic) domain. ${ }^{4}$ This paper describes the simulation of the converter and associated control system that regulates energy transfer to and from the flywheel. A simpler representation of the motor/generator was employed in the simulation as described later in this paper.

\section{SYSTEM DESCRIPTION}

Inertial energy stored in a flywheel varies as the square of its rotational speed. This permits the flywheel energy storage system a depth of discharge of 90 percent (which is possible for a battery system but at the expense of life) for a reduction in speed to only onethird. For this flywheel, the operating speed has been established to be between $60000 \mathrm{rpm}(\max )$ and 20000 $\mathrm{rpm}(\mathrm{min})$. The flywheel rotational inertia constant is 
selected according to the energy storage needed, and the flywheel rotating speed simply goes up or down during charge or discharge within the operating speed limits. The mechanical and structural properties of the wheel as well as the reliability of the shaft bearings govern the upper limit. Further lowering of the lower speed limit does not yield any significant depth of discharge. Figure 1 shows the energy flow in a flywheel system for charge and discharge conditions. Figure 2 shows a top-level diagram of the simulated flywheel system. For clarity, only details of phase A are shown.

A two-pole, three-phase, Permanent Magnet Synchronous Motor/Generator (PMSM) is shaft-coupled to the flywheel. The voltage magnitude and frequency at the machine winding terminals are directly proportional to the speed of rotation. Thus, during motor action, for example, an inverter output with the desired voltage and frequency profile is made available to transfer energy to the motor and, hence, to the flywheel. Naturally, the reverse process takes place when energy is transferred in the opposite direction.

For a typical synchronous motor, changing the frequency of the applied voltage changes the motor speed. This is known as open-loop speed control. However, in the present case, the speed control is also based on shaft position feedback, the closed-loop control. Briefly, only the winding whose axis aligns with the pole axis is energized, successively, to create torque. Hence, it is necessary to know the location of the pole axis or the shaft position. It may be noted, however, that these considerations are not relevant in the present simulation, because there is no explicit shaft rotation in the simplified model of the synchronous machine.

The power electronics (Fig. 3) in a FESU converts a dc source to an ac power (charge mode) and vice versa (discharge mode). Although there could be many ways to bring this about, for this simulation, three singlephase, dc-to-ac converters were connected to the three motor terminals. The Y-point of the motor winding remained unconnected. The dc ends of the converters were connected, in parallel, to the dc bus. Appropriate filters are installed between the $\mathrm{dc}$ bus and the converter switches (S1A and S2B) to mitigate the effects of harmonics caused by the switching action. The motor winding terminal was connected to the common point between the switches. Thus, any current entering or leaving a motor winding was returned via the other two windings and the appropriate closed switches or the diodes in parallel (actually the body diode). A closing and opening sequence for the switches was established to transfer power between $\mathrm{dc}$ and ac operation.
As mentioned earlier, the controller (Fig. 4) operated the power electronic switches to excite the motor windings according to the shaft position. For this simulation, the controller also limited the currents in the switches and the windings to 150 and $100 \mathrm{~A}$, respectively. Reference values of the currents to be limited were compared with the actual currents that were fed back, and error signals were generated to drive the pulse-width modulator that operates the switch (Fig. 5). Similarly, other desirable quantities could be controlled, such as the rate of change of the flywheel speed and the rate of the charge or discharge current. The controller could issue a command to reverse operation from charge to discharge. A reference sine wave controlled errors in the pulse-width modulator (PWM). The frequency of this sine wave determined the frequency of the machine output voltage and, therefore, the flywheel speed.

Certain observations can be made with respect to the switch action (see Fig. 5). During a charge operation, only switch SIA was pulse-width modulated while switch S2B worked in an on-off mode. During a discharge operation, only switch $\mathrm{S} 2 \mathrm{~B}$ was pulse-width modulated, while switch S1A was open all the time. However, the body diode of SIA would conduct the signal if the appropriate bias voltage was available.

\section{MOTOR MODEL}

An electrical, not an electromechanical, model was used for this simulation. Thus, the model could not simulate the motor torque equation as a mechanical quantity. However, it could simulate the electrical response by virtue of its back electromagnetic force (EMF) and the winding parameters. Each phase of the motor consists of an R-L series circuit, in series with a sinusoidal voltage source that represented the back EMF (i.e., the air gap voltage). The Y-point was left unconnected. Presently, the magnitude and frequency of the back EMF are held constant for a given case. Thus, with the motor/generator, we are able to simulate power exchange but not an energy exchange. Or the simulation can take place with the machine at a fixed rotational speed. Motor simulation data are shown in Table I.

During normal operation the rotor speed will not go below $20000 \mathrm{rpm}$. At that speed, the voltage and frequency are one-third of their values at the maximum speed. The current rating does not change. This model assumes that the rotor is uniformly round and that saliency effects are neglected. These will be considered in the next phase of modeling. 
TABLE I-SIMULATION DATA FOR THE THREE-PHASE, TWO-POLE PERMANENT MAGNET SYNCHRONOUS MOTOR/GENERATOR

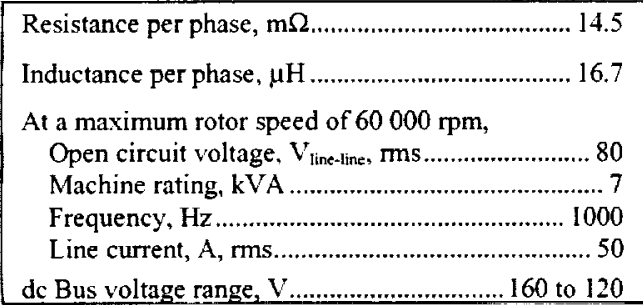

\section{SCOPE OF SIMULATION}

As was mentioned earlier, the motor operation was simulated at a constant speed. At this chosen speed we could simulate charge or discharge action. Because of the magnitude of both the $\mathrm{dc}$ and ac voltages, bucking occurred during charging and boosting occurs during discharging. Thus, in a given situation, the level of power being transferred depended on the levels of dc and ac voltages encountered. Keeping this in view, we ran five simulations, as shown in Table II. These cases cover all the dc and ac voltage extremes. Also, as pointed out earlier, the voltage magnitude and frequency changed proportionally with the number of revolutions per minute.

TABLE II.--SIMULATIONS BASED ON AC AND DC OPERATING VOLTAGES

\begin{tabular}{|c|c|c|c|c|c|}
\hline Case & $\begin{array}{c}\text { Flywheel } \\
\text { speed, } \\
\text { rpm }\end{array}$ & $\begin{array}{c}\text { Back EMF, } \\
\text { line-neutral, } \\
\text { peak volts, } \\
\text { V }\end{array}$ & $\begin{array}{c}\text { Frequency, } \\
\mathrm{Hz}\end{array}$ & $\begin{array}{c}\text { dc Bus } \\
\text { voltage, } \\
\mathrm{V}\end{array}$ & $\begin{array}{c}\text { Figure } \\
\text { showing } \\
\text { results }\end{array}$ \\
\hline 1 & 40000 & 43 & 666 & 140 & 6 \\
2 & 20000 & 22 & 333 & 120 & 7 \\
3 & 20000 & 22 & 333 & 160 & 8 \\
4 & 60000 & 65 & 1000 & 120 & 9 \\
5 & 60000 & 65 & 1000 & 160 & 10 \\
\hline
\end{tabular}

\section{SIMULATION TOOL}

Saber, a simulation software package developed by Analogy, Inc. (now part of Avant! ${ }^{5}$ ), was used for these simulations. The tool permits complete circuit simulation as well as control simulation using logic devices.

\section{SIMULATION RESULTS}

The five cases delineated in Table II were simulated, and the resulting data plots are shown in Figures 6 to 10 . Case 1 has voltage values midway between the extremes chosen in the other cases. The results shown are steady-state operations over an arbitrary length of time. For each case, both charge and discharge operations are shown. Cases 2 to 5 represent pairings of the high and low values of the ac and dc voltages. These are possible conditions of operation.

Figure 6 shows simulation results for case 1, including the levels of charge and discharge and the enable commands needed to achieve charge, idle, and discharge operations. The phase- $A$ back EMF is also shown. By definition, this is a sine wave of a specified magnitude and frequency. Next shown is a rectified version of the phase-A current. Lastly, the dc current output of the FESU to the system dc bus is shown. Clearly, this current is negative during the charge mode, as it should be.

Figures 7 to 10 show results for the remaining simulations from Table II. Only rectified phase-A current and the dc current into the $\mathrm{dc}$ bus are shown for comparison. The high and low values of the ac voltages denote conditions at the operating range of the flywheel, whereas the high and low values of the dc voltage denote values most likely available at the beginning and end of the space station's useful life. Note that the motor current was limited to $100 \mathrm{~A}$ (as previously mentioned) in all the cases except case 4.

As discussed earlier, bucking and boosting take place in charge and discharge modes, respectively, mainly because of the voltage levels available. The amount of boosting possible also depends on the commutating inductance (the winding inductance in this case). We verified that we could make the discharge current nearly zero by arbitrarily increasing the dc voltage or decreasing the ac voltage (results not shown).

The switch model consists of a nearly ideal switch in parallel with an ideal diode (the body diode). The motor winding current waveforms do not look like rectified sine waves. In fact, one-half of the waveform looks quite distorted. This is caused by unregulated current in the control method during this period. Snubber circuits, which were not modeled, will also influence the shape of these waveforms.

\section{CONCLUDING REMARKS}

Interaction of the electronic dc-to-ac power converter, which connects the dc bus to the flywheel was demonstrated at constant flywheel speed, and the exchange and reversal of currents between the two was shown. A simplified version of the machine model was used which precludes the simulation of the electromechanical behavior of the machine. Work is in progress to upgrade the models, which will lead to a demonstration of the energy exchange between the dc bus and the flywheel. 


\section{REFERENCES}

1. Patel, Mukund R.: Flywheel Energy Storage for Spacecraft Power Systems. Proceedings of the 34th Intersociety Energy Conversion Engineering Conference, SAE Paper 1999-01-2589, 1999.

2. Christopher, D.: Aerospace Flywheel Development Program. http://space-power.grc.nasa.gov/ppo/ flywheel/ last modified Nov. 1, 1999, accessed June 28, 2000.

3. Truong, L.V.; Wolff, F.J.; and Dravid, N.V.: Simulation of the Interaction Between Flywheel Energy Storage and Battery Energy Storage on the International Space Station. NASA/TM-2000210341,2000 . Will be available online: http://gltrs.grc.nasa.gov/cgi-bin/GLTRS/ browse.pl?2000/TM-210341.html
4. Ansoft Corporation. http://www.ansoft.com copyrighted 2000, accessed June 28, 2000.

5. Avant! Power-Use Saber for Component to Circuit Level to System Level Power Designs in all Types of Industries. http:www.analogy.com/powerf default.htm copyrighted 2000 , accessed July 5 , 2000.

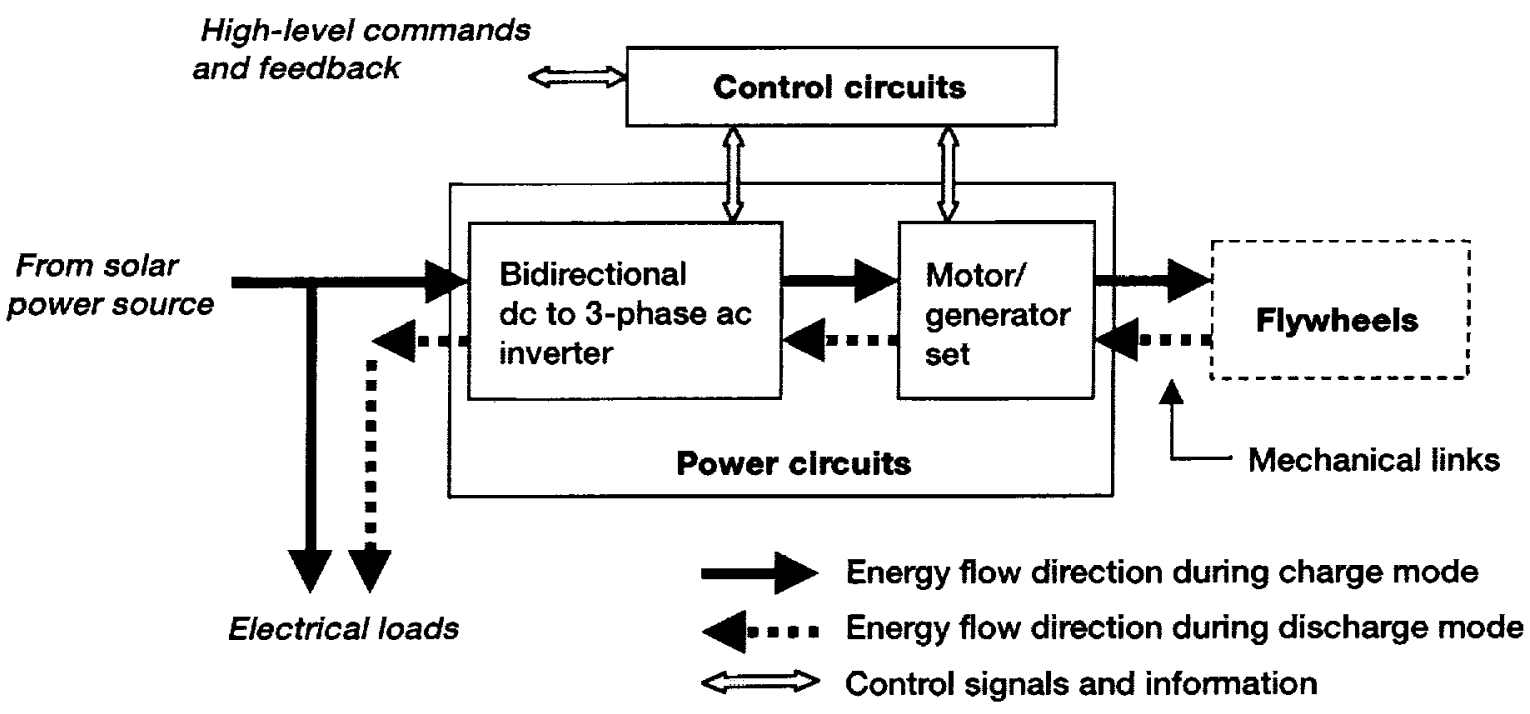

Figure 1.-Energy transfer diagram for Flywheel Energy Storage Unit. 


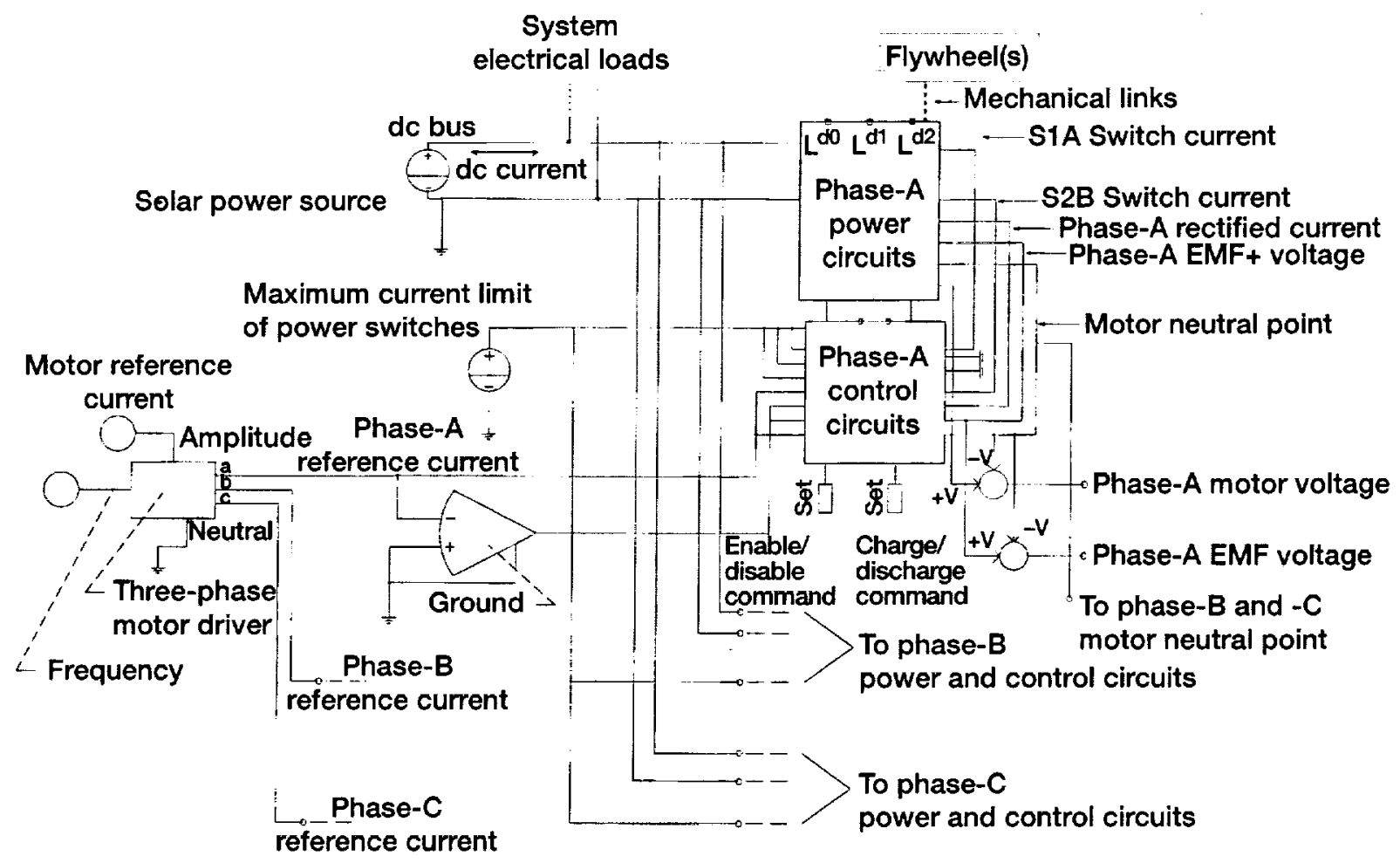

Figure 2.-Top-level diagram of the simulated flywheel system.

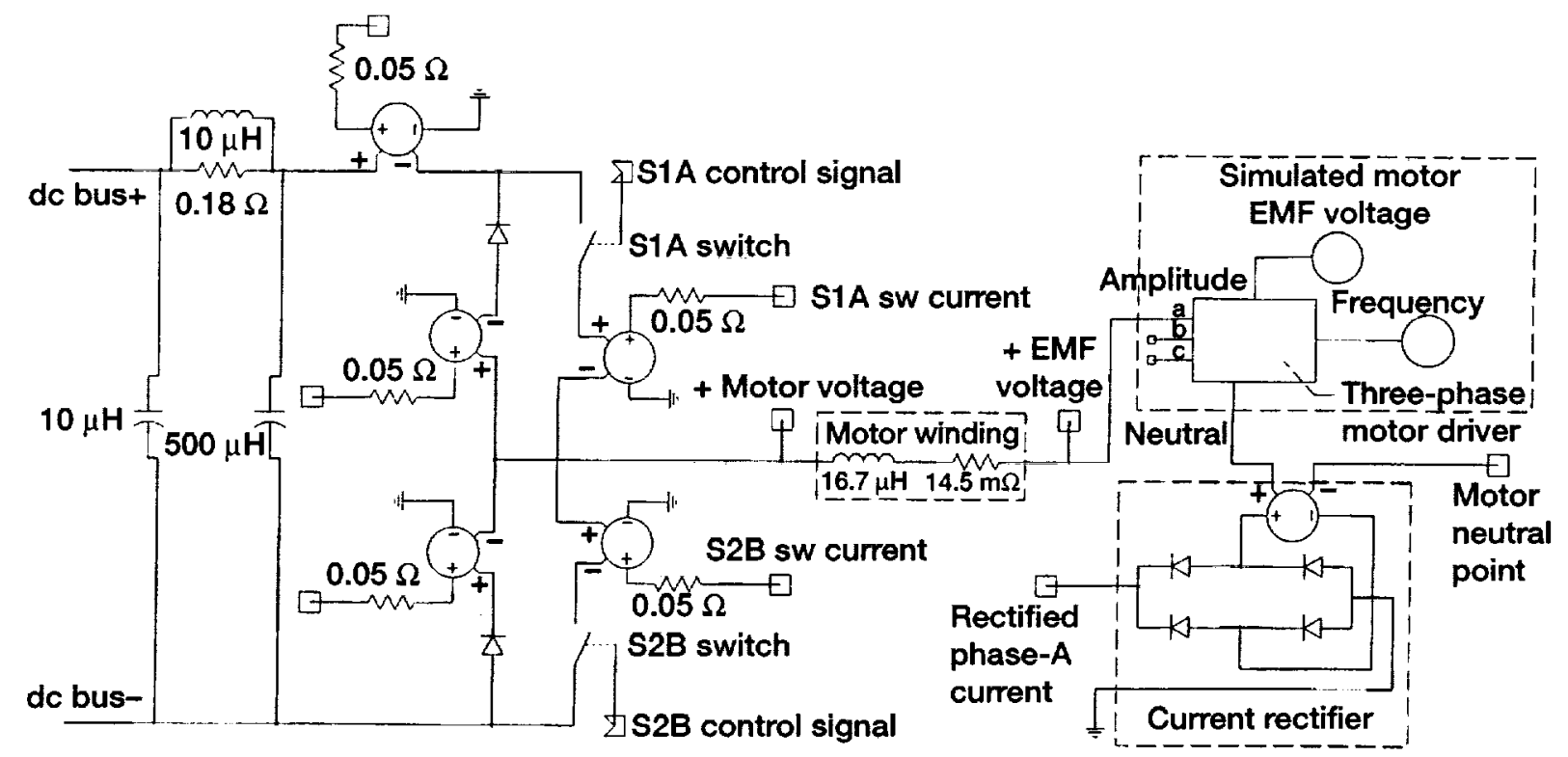

Figure 3.-Details of phase-A power circuits. 


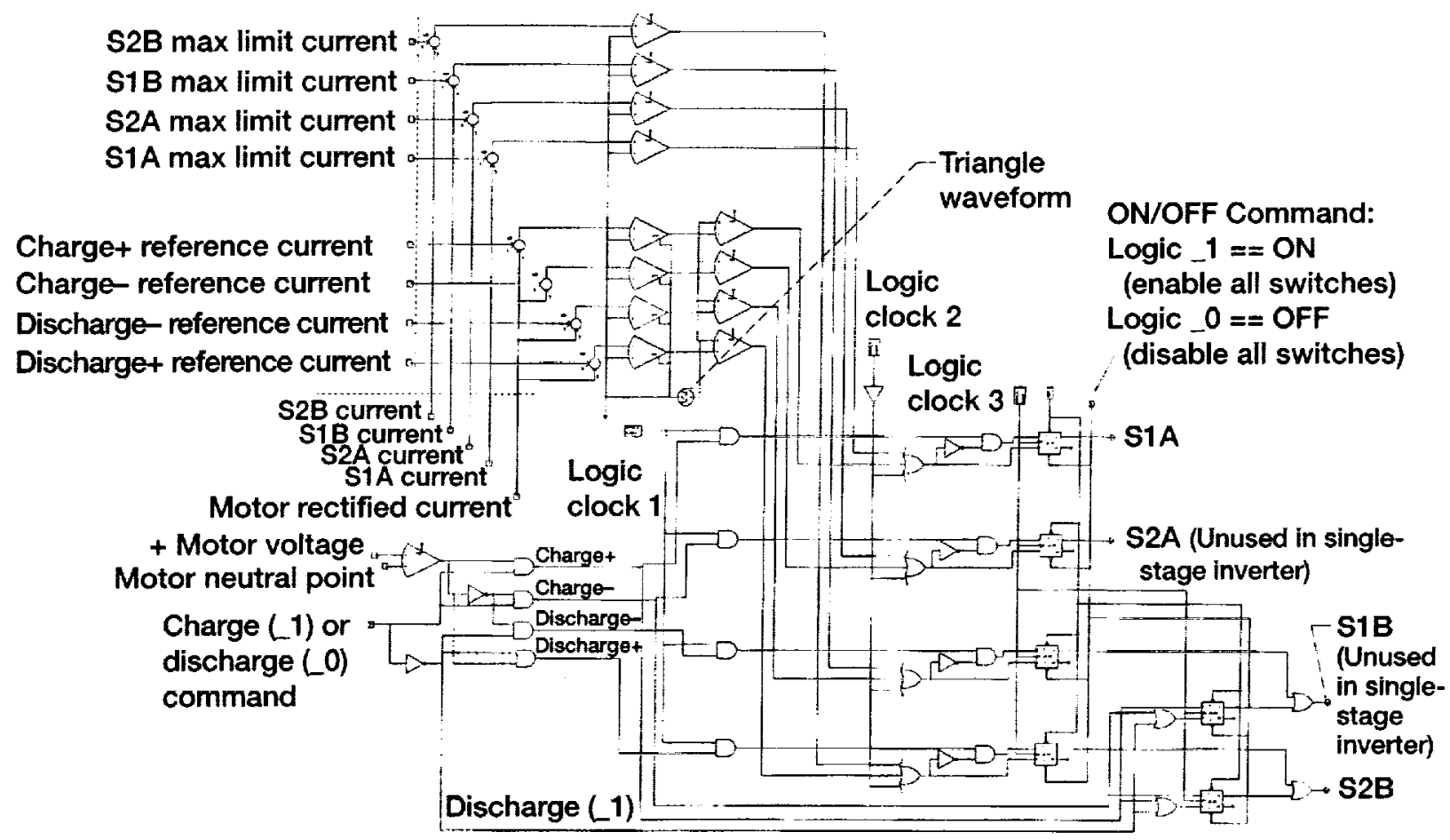

Figure 4.-Details of phase-A control circuits.

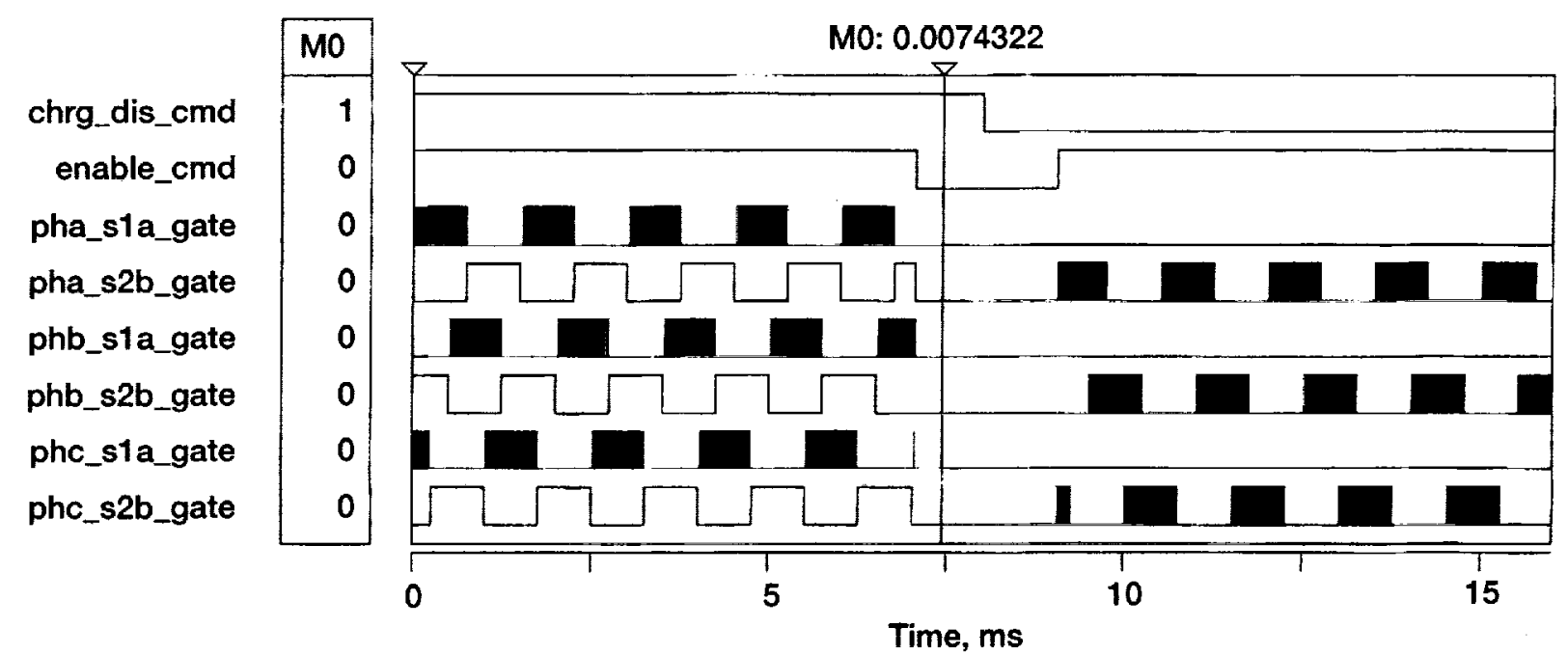

Figure 5.-Typical pulse-width-modulated drive signals for the power electronic switches. Charge mode, 0 to $7 \mathrm{~ms}$; idle mode, 7.1 to $9 \mathrm{~ms}$; discharge mode, 9.1 to $16 \mathrm{~ms}$. 

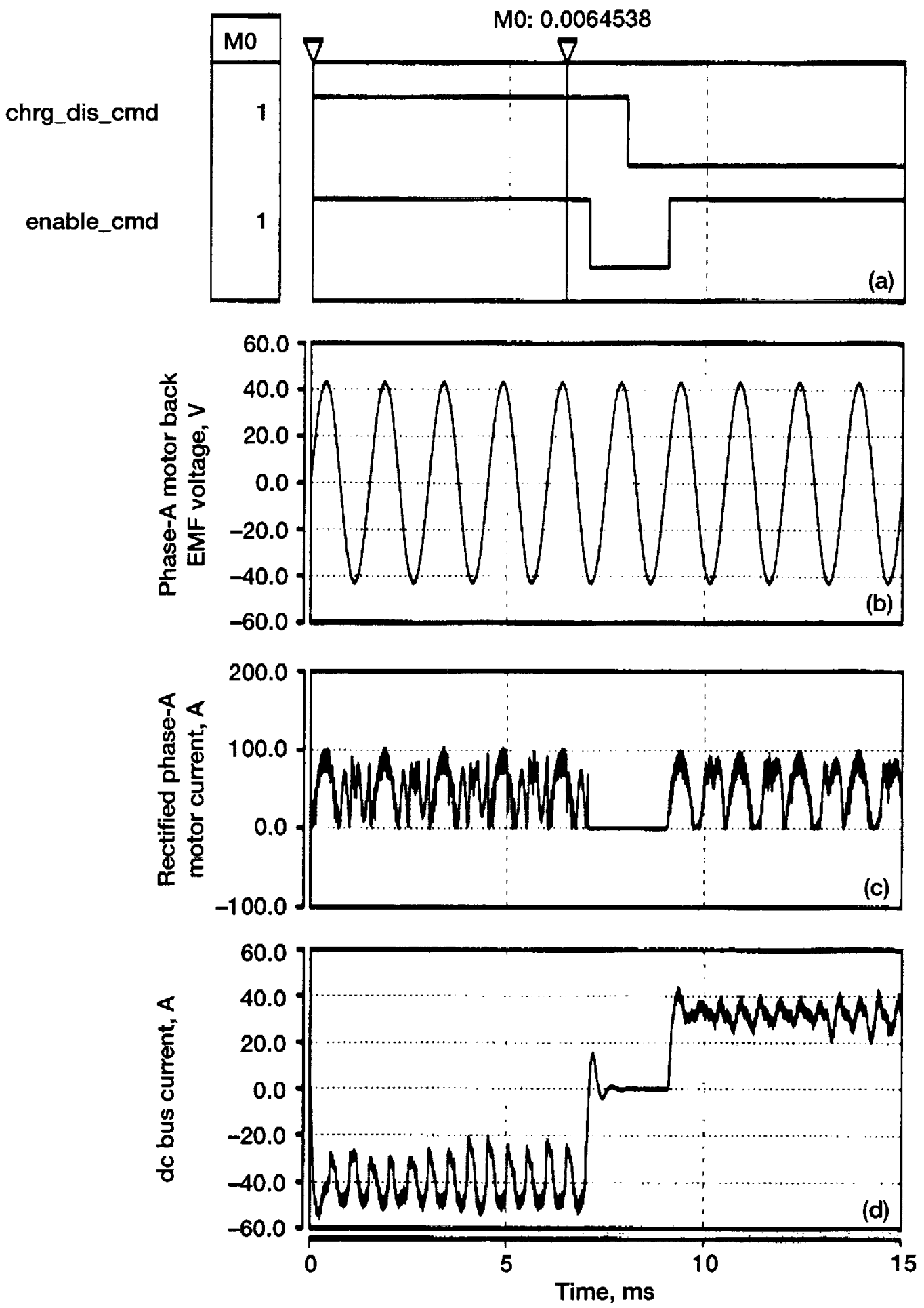

Figure 6.-Simulation results for case 1. Motor electromotive force (EMF) voltage, $43 \mathrm{Vac}$ (line-neutral, peak); dc bus voltage, $140 \mathrm{Vdc}$. (a) Charge, idle, and discharge commands needed for operations. (b) Phase-A motor back EMF voltage. (c) Rectified phase-A motor current. (d) dc bus current. 


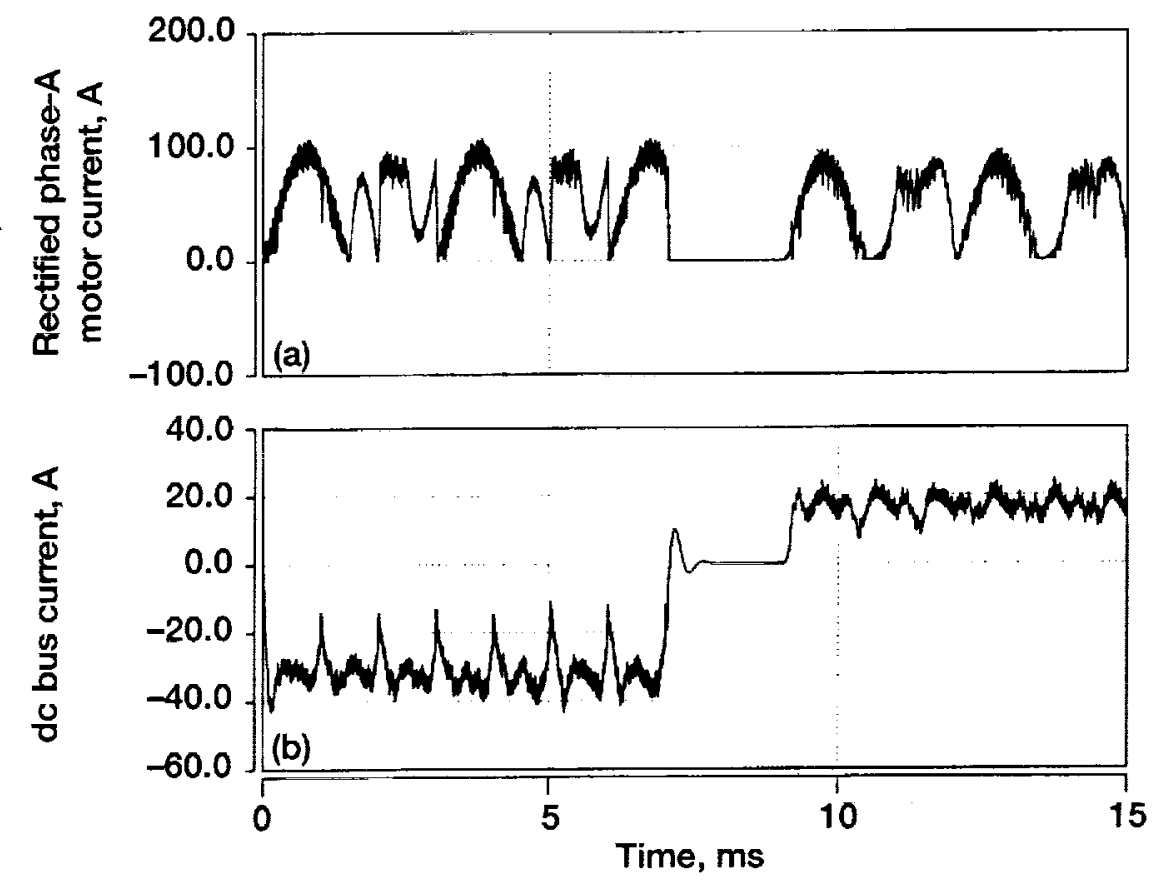

Figure 7.-Simulation results for case 2. Motor electromotive force (EMF) voltage, 22 Vac (line-neutral, peak); dc bus voltage, 120 Vdc. (a) Rectified phase-A motor current. (b) dc bus current.

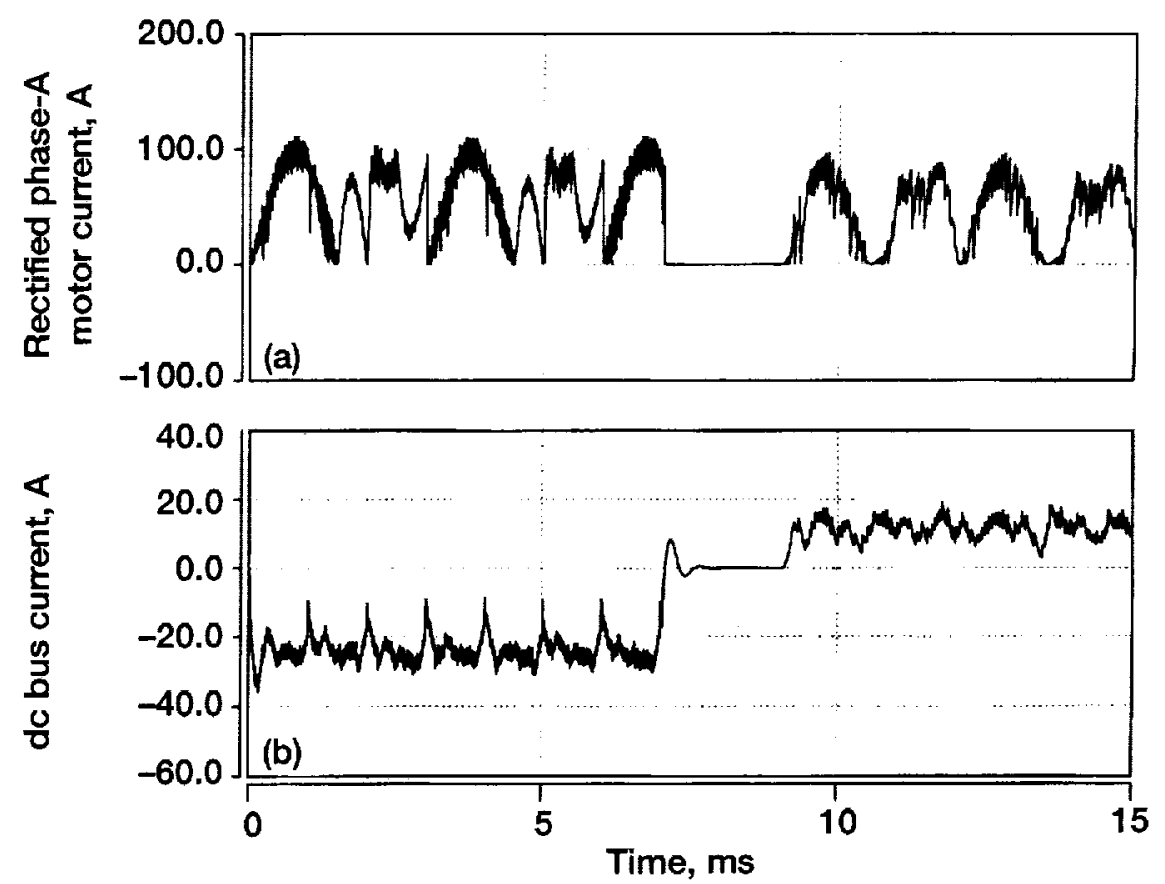

Figure 8.-Simulation results for case 3. Motor electromotive force (EMF) voltage, 22 Vac (line-neutral, peak); dc bus voltage, $160 \mathrm{Vdc}$. (a) Rectified phase-A motor current. (b) dc bus current. 


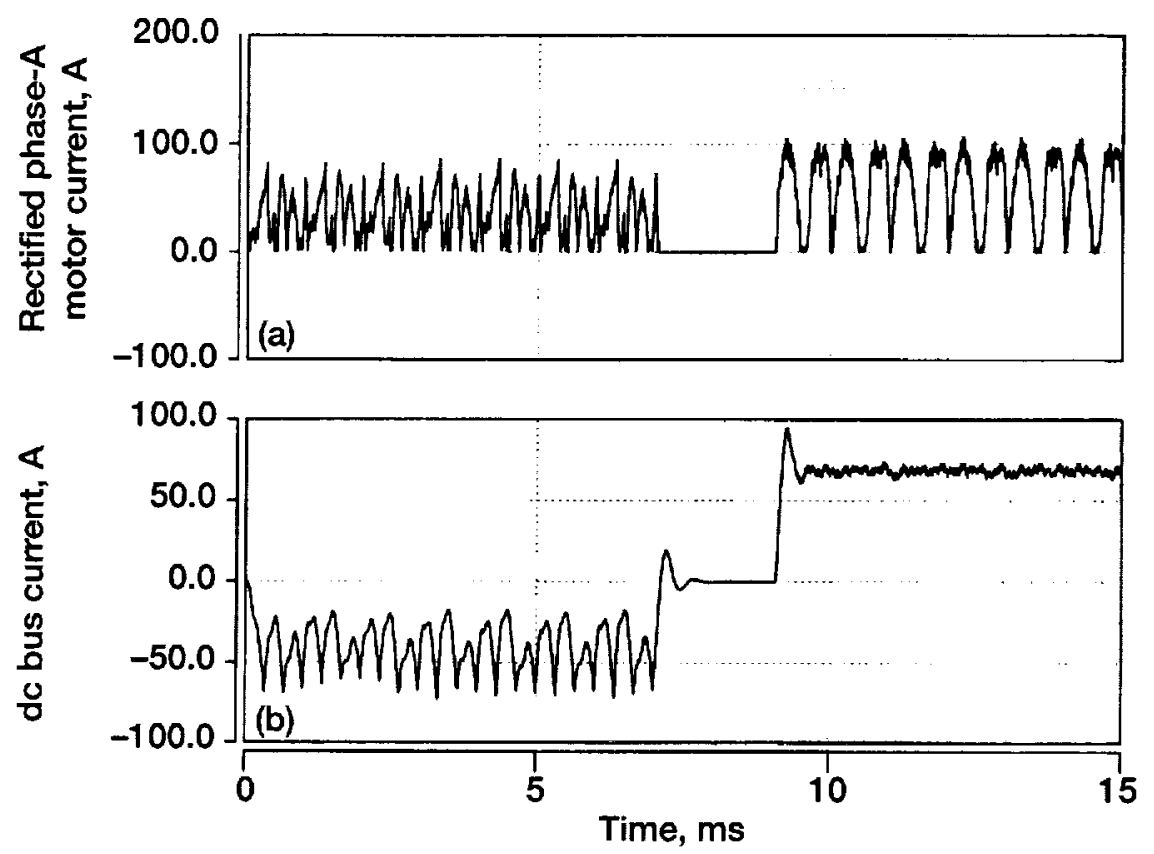

Figure 9.-Simulation results for case 4. Motor electromotive force (EMF) voltage, $65 \mathrm{Vac}$ (line-neutral, peak); dc bus voltage, $120 \mathrm{Vdc}$.

(a) Rectified phase-A motor current. (b) dc bus current.

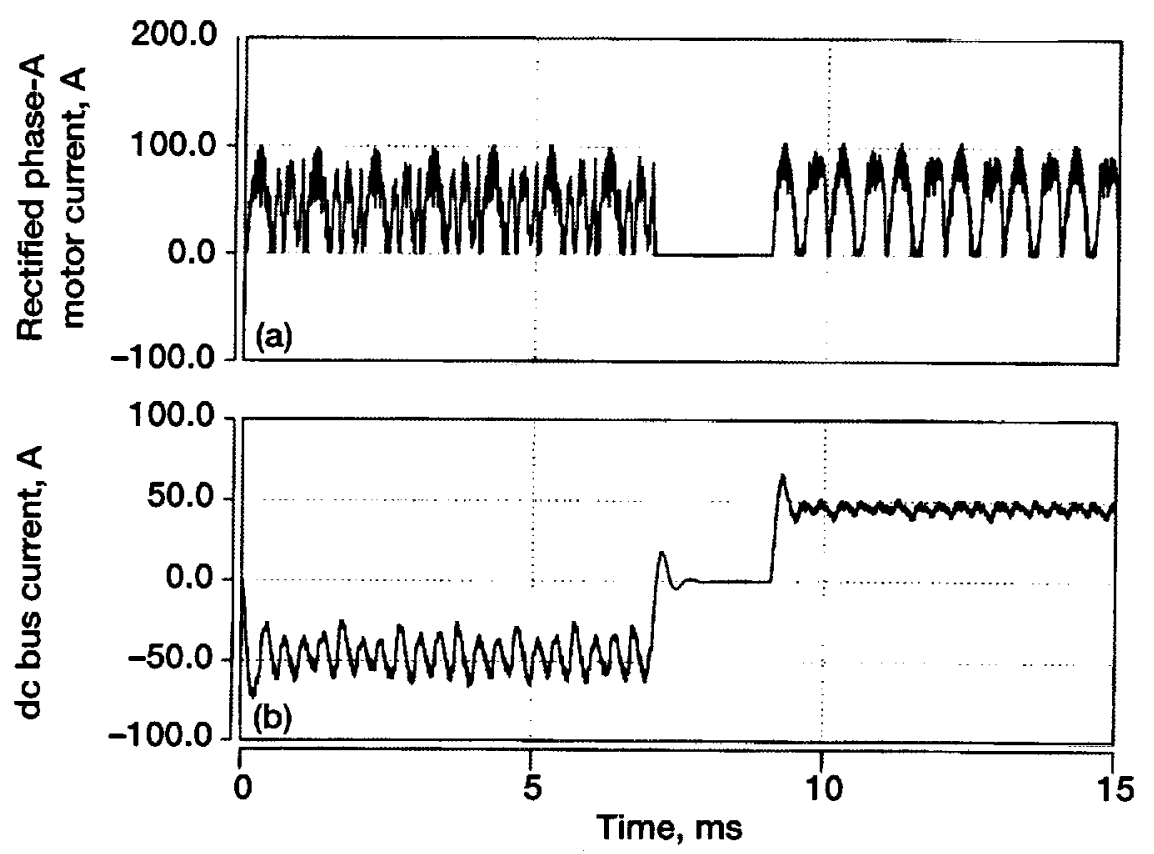

Figure 10.-Simulation results for case 5. Motor electromotive force (EMF) voltage, $65 \mathrm{Vac}$ (line-neutral, peak); dc bus voltage, $160 \mathrm{Vdc}$. (a) Rectified phase-A motor current. (b) dc bus current. 
Public reporting burden for this collection of information is estimated to average 1 hour per response, including the time for reviewing instructions, searching existing data sources, gathering and maintaining the data needed, and completing and reviewing the collection of information. Send comments regarding this burden estimate or any other aspect of this Davis Highway, Sulte 1204, Arlington, VA 22202-4302, and to the Otfice of Management and Budget, Paperwork Reduction Project (0704-0188), Washington, DC 20503.

\begin{tabular}{l|l|l|} 
1. AGENCY USE ONLY (Leave blank) & 2. REPORT DATE & 3. REPORT TYPE AND DATES COVERED
\end{tabular}

\begin{tabular}{|c|c|} 
July 2000 & Technical Memorandum \\
\hline
\end{tabular}

4. TITLE AND SUBTITLE

5. FUNDING NUMBERS

Simulation of a Flywheel Electrical System for Aerospace Applications

6. AUTHOR(S)

WU-494-21-11-00

Long V. Truong, Frederick J. Wolff, and Narayan V. Dravid

7. PERFORMING ORGANIZATION NAME(S) AND ADDRESS(ES)

National Aeronautics and Space Administration

John H. Glenn Research Center at Lewis Field

Cleveland, Ohio 44135-3191

8. PERFORMING ORGANIZATION REPORT NUMBER

E-12361

9. SPONSORING/MONITORING AGENCY NAME(S) AND ADDRESS(ES)

National Aeronautics and Space Administration

Washington, DC 20546-0001

10. SPONSORING/MONITORING AGENCY REPORT NUMBER

NASA TM-2000-210242

AIAA-2000-2908

11. SUPPLEMENTARY NOTES

Prepared for the 35th Intersociety Energy Conversion Engineering Conference sponsored by the American Institute of Aeronautics and Astronautics, Las Vegas, Nevada, July 24-28, 2000. Responsible person, Long V. Truong, organization code $5490,(216) 433-6153$.

12a. DISTRIBUTION/AVAILABILITY STATEMENT

12b. DISTRIBUTION CODE

Unclassified - Unlimited

Subject Category: 20

Distribution: Nonstandard

This publication is available from the NASA Center for AeroSpace Information, (301) 621-0390.

13. ABSTRACT (MaxImum 200 words)

A Flywheel Energy Storage Demonstration Project was initiated at the NASA Glenn Research Center as a possible replacement for the battery energy storage system on the International Space Station (ISS). While the hardware fabrication work was being performed at a university and contractor's facility, the related simulation activity was begun at Glenn. At the top level, Glenn researchers simulated the operation of the ISS primary electrical system (as described in another paper) with the Flywheel Energy Storage Unit (FESU) replacing one Battery Charge and Discharge Unit (BCDU). The FESU consists of a Permanent Magnet Synchronous Motor/Generator (PMSM), which is connected to the flywheel; the power electronics that connects the PMSM to the ISS direct-current bus; and the associated controller. The PMSM model is still under development, but this paper describes the rest of the FESU model-the simulation of the converter and the associated control system that regulates energy transfer to and from the flywheel.

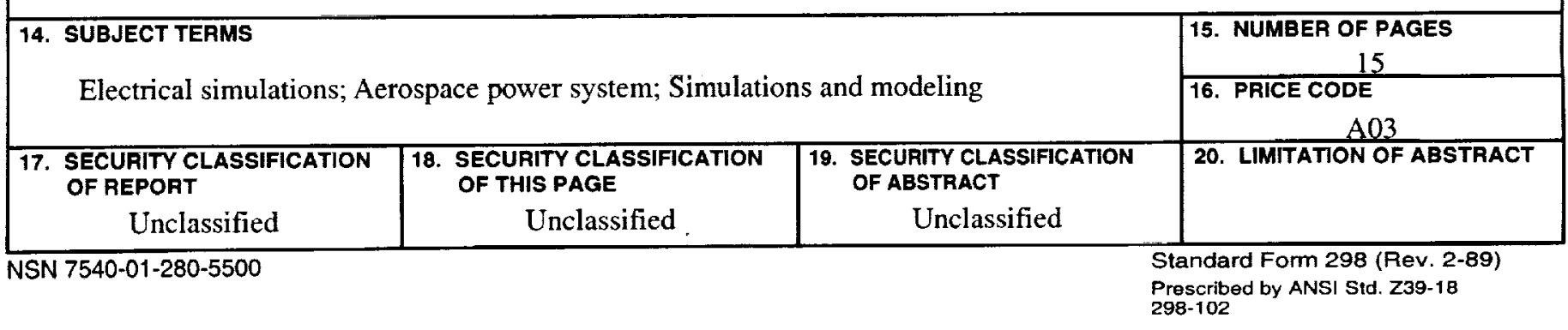

